\title{
The Similarities and Differences between Intracranial and Spinal Ependymomas : A Review from a Genetic Research Perspective
}

\author{
Chang-Hyun Lee, M.D., ${ }^{1}$ Chun Kee Chung, M.D., Ph.D., ${ }^{2,3,4,5,6}$ Jung Hun Ohn, M.D., ${ }^{7 *}$ Chi Heon Kim, M.D., Ph.D. ${ }^{2,3,4,5}$ \\ Department of Neurosurgery, ${ }^{1}$ Ilsan Paik Hospital, Inje University College of Medicine, Goyang, Korea \\ Department of Neurosurgery, ${ }^{2}$ Seoul National University Hospital, Seoul, Korea \\ Department of Neurosurgery, ${ }^{3}$ Seoul National University College of Medicine, Seoul, Korea \\ Neuroscience Research Institute, ${ }^{4}$ Seoul National University Medical Research Center, Seoul, Korea \\ Clinical Research Institute, ${ }^{5}$ Seoul National University Hospital, Seoul, Korea \\ Department of Brain and Cognitive Sciences, ${ }^{6}$ Seoul National University College of Natural Sciences, Seoul, Korea \\ Bioinformatics, ${ }^{7}$ Samsung Gene Institute, Samsung Medical Center, Seoul, Korea
}

\begin{abstract}
Ependymomas occur in both the brain and spine. The prognosis of these tumors sometimes differs for different locations. The genetic landscape of ependymoma is very heterogeneous despite the similarity of histopathologic findings. In this review, we describe the genetic differences between spinal ependymomas and their intracranial counterparts to better understand their prognosis. From the literature review, many studies have reported that spinal cord ependymoma might be associated with NF2 mutation, NEFL overexpression, Merlin loss, and 9q gain. In myxopapillary ependymoma, NEFL and HOXB13 overexpression were reported to be associated. Prior studies have identified HIC-1 methylation, 4.1B deletion, and 4.1R loss as common features in intracranial ependymoma. Supratentorial ependymoma is usually characterized by NOTCH-1 mutation and p75 expression. TNC mutation, no hypermethylation of RASSF1A, and GFAP/NeuN expression may be diagnostic clues of posterior fossa ependymoma. Although MEN1, TP53, and PTEN mutations are rarely reported in ependymoma, they may be related to a poor prognosis, such as recurrence or metastasis. Spinal ependymoma has been found to be quite different from intracranial ependymoma in genetic studies, and the favorable prognosis in spinal ependymoma may be the result of the genetic differences. A more detailed understanding of these various genetic aberrations may enable the identification of more specific prognostic markers as well as the development of customized targeted therapies.
\end{abstract}

Key Words : Ependymoma $\cdot$ Genetics $\cdot N F 2 \cdot$ Spinal $\cdot$ Intracranial.

\section{INTRODUCTION}

Ependymomas are glial tumors that are thought to arise from primitive ependymal or subependymal cells in the vicinity of the ventricles and remnants of the central spinal canal ${ }^{38)}$. Microscopically, ependymomas are moderately cellular gliomas corresponding to WHO grade 2 neoplasms and are well demarcated with a sharp tumor-parenchyma interface ${ }^{41)}$. In aspect of intracranial ependymomas, so far the cure for this disease has eluded us and despite its histological benignancy, the majority of patients will die from their disease ${ }^{41)}$. Although intracranial ependymoma is associated with an aggressive clinical course and poor progno- sis, spinal ependymoma is linked with an indolent clinical course and good prognosis ${ }^{38,42,46)}$. The more difficult thing to estimate clinical course of ependymal tumors is that they are heterogeneous with regard to morphology, localization, and age at first clinical manifestation ${ }^{7)}$. In children, $90 \%$ of ependymomas develop in the intracranial region and are associated with frequent recurrences ${ }^{18,38,46,50)}$. In adults, $60 \%$ of ependymomas develop in the spinal cord, and recurrence is rare ${ }^{38,50)}$. The differences between intracranial and spinal ependymomas make the extrapolation of data from one to the other difficult ${ }^{50)}$. Moreover, recent findings suggest that the histologic diagnosis of ependymomas may be insufficient for assigning an appropriate risk stratifica-

• Received : November 20, 2015 •Revised : November 20, 2015 •Accepted : January 1, 2016

*Move to : Department of Internal Medicine, Seoul National University Bundang Hospital, Seongnam, Korea

- Address for reprints : Chun Kee Chung, M.D., Ph.D.

Department of Neurosurgery, Seoul National University Hospital, Seoul National University College of Medicine, 101 Daehak-ro, Jongno-gu, Seoul 03080, Korea

Tel : +82-2-2072-2357, Fax : +82-2-744-8459, E-mail : chungc@snu.ac.kr

- This is an Open Access article distributed under the terms of the Creative Commons Attribution Non-Commercial License (http://creativecommons.org/licenses/by-nc/3.0) which permits unrestricted non-commercial use, distribution, and reproduction in any medium, provided the original work is properly cited. 
tion strategy ${ }^{49)}$.

Although intracranial and spinal ependymomas are histopathologically similar, their molecular biology is very heterogeneous, and they possess different DNA copy number alterations, messenger-RNA expression profiles, and genetic and epigenetic alterations as well as diverse transcriptional programs $\mathrm{s}^{19,24,27,29,40,46)}$. The genetic landscape of ependymoma is also heterogeneous; these tumors show mostly complex aberration patterns with frequent deletions or gains of chromosomes, and the main losses occur on chromosomes 1p, 4q, 6q, 9, 10, 13q, 16, 17, 19q, 20q, and $22 q^{16,17,35,47,48,51)}$. Some genetic researches revealed substantially different frequencies of genetic aberrations for different tumor locations ${ }^{71,2,1,44)}$. Therefore, these results support the hypothesis that the histological entity "ependymoma" in fact comprises a group of related diseases that likely require different approaches and treatments ${ }^{17,28,40}$. Furthermore, conventional therapies may fail to control tumor growth and progression due to the inherent heterogeneity of ependymoma, as demonstrated by analyses of their genetic and molecular anomalies ${ }^{19,49)}$. In this review, we describe the genetic differences between spinal ependymomas and their intracranial counterparts to better understand their prognosis. Research to improve our knowledge of the genetic differences between spinal and intracranial ependymomas will be essential to guide therapeutic strategies and estimate their prognoses.

\section{Statistical analysis}

For the statistical analyses, we used the $\mathrm{R}$ : A language and environment for statistical computing (R Foundation for Statistical Computing, Vienna, Austria) and the R-package "exact2×2" which is a Fishers exact test tool. If the statistical significance of a difference in genes, proteins, and chromosomal mutations was not described in each paper, we calculated the $p$-value using Fisher's exact 2 by 2 frequency probability to compare spinal ependymoma with its intracranial counterpart. For all tests, a level of $p<0.05$ was considered statistically significant.

\section{MOLECULAR GENETIC ABERRATIONS}

Spinal cord ependymomas frequently exhibit mutations in NF2, NEFL overexpression, Merlin loss, and 9q gain, while intracranial ependymomas do not ${ }^{4,5,7,12,38,49}$. In addition, spinal cord ependymomas involve HES1, MYC, and GFAP overexpression ${ }^{12,13}$. In myxopapillary ependymomas (MPEs), NEFL overexpression is frequently observed ${ }^{4}$. Intracranial ependymomas commonly display HIC-1 methylation, $4.1 \mathrm{~B}$ deletion, and $4.1 \mathrm{R} \operatorname{loss}^{30,44)}$. Supratentorial ependymoma display mutations in NOTCH-1, NeuN and p75 overexpression, and low expression of GFAP protein ${ }^{12,13)}$. Mutation in TNC, lack of hypermethylation in RASSF1A, and GFAP/NeuN expression may provide clues for the diagnosis of posterior fossa ependymoma ${ }^{12-14)}$. Although MEN1 and TP53 mutations have been rarely reported in ependymoma, they might be related to its recurrence or metastasis ${ }^{5,7,21)}$. In turn, NEFL over-

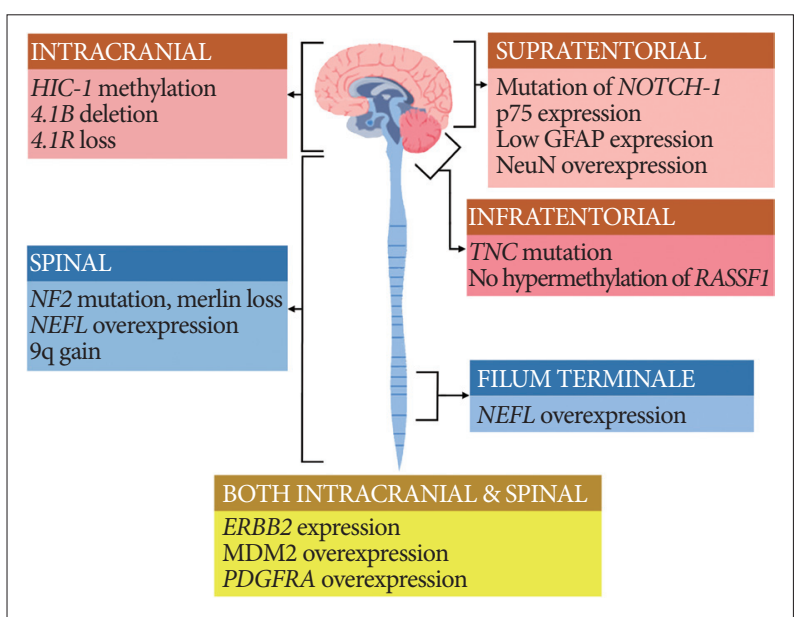

Fig. 1. Graphical summary of the genes, proteins, and chromosomal aberrations associated with ependymomas.

expression indicates a good prognosis and longer progressionfree survival ${ }^{2}$. A graphical illustration of the key genes, proteins, and chromosomal aberrations related to the ependymoma subgroups according to tumor location is given in Fig. 1 .

\section{NF2 and Merlin}

A variety of numerical and structural chromosomal abnormalities have been found to be associated with ependymomas; inactivation of NF2 gene, as well as sporadic mutations in NF2, on chromosome 22q12 have been well documented in ependymomas ${ }^{7,27,34,38)}$. The importance of the NF2 gene to ependymoma pathogenesis is further emphasized by the observation that NF2 gene mutations and the loss of Merlin, the protein encoded by the NF2 gene, are found in 30-71\% of sporadic (non-syndromal) ependymomas ${ }^{9,38}$. Among 4 studies included in this review, 2 studies showed that mutation of NF2 gene is observed only in spinal ependymoma and not in intracranial ependymoma, as shown in Table $1^{5,7)}$. Another study reported that NF2 loss was strongly associated with spinal ependymoma at the protein level, Merlin, whereas at the DNA level, this was only a trend ${ }^{38}$. Some studies reported that NF2 mutations were found in a high percentage of spinal ependymoma cases (WHO grade II) especially and in few cases of MPE (WHO grade I), subependymoma (WHO grade I), and anaplastic ependymoma (WHO grade III) as well as all intracranial ependymomas ${ }^{7,27)}$.

\section{HIC1}

Hypermethylated in cancer 1 (HIC1) gene is located on chromosome 17p13.3. Although only one study dealt with HIC1 gene in ependymoma, it clearly demonstrated that low or absent expression of the $\mathrm{HICl}$ gene is frequently found in human ependymomas and that hypermethylation was significantly more common in intracranial ependymomas than spinal tumors, as shown in Table 1 (intracranial : $94 \%$ vs. spinal : $65 \% ; p=0.019)^{44)}$. A chromosomal study reported that loss of chromosome arm 17p DNA sequences was common in sporadic pediatric intracranial ep- 
endymomas and many different human tumors, including gliomas and medulloblastomas ${ }^{43)}$.

\subsection{B, DAL-1, and 4.1R}

Both $4.1 B$ and $D A L-1$ genes are located on chromosome $18 \mathrm{p} 11$ and are involved in different mechanisms that modulate cell growth, motility, adhesion, and cytoskeleton organization ${ }^{45)}$. Inactivation of $4.1 B$ and $D A L-1$ gene expression may lead to tumorigenesis and/or promote tumor progression ${ }^{45)}$. One study reported that $4.1 B$ deletions were commonly observed in intra- cranial ependymoma compared with its spinal counterpart in Table 1 (intracranial : $49 \%$ vs. spinal : $25 \%$; $p=0.038$ ), and protein $4.1 \mathrm{~B}$ loss was seen in 3 of 4 intracranial tumors and 1 of 5 spinal cord tumors in Table $2^{30)}$. Losses of DAL-1 gene and DAL- 1 protein were more frequently observed in intracranial ependymomas than in the spinal cord form, although this difference did not reach statistical significance ${ }^{38)}$. Among another proteins in the 4.1 family in Table 2, loss of protein 4.1R expression was statistically associated with intracranial location (intracranial : $88 \%$ vs. spinal : $47 \% ; p=0.003$ ) and young age (pediatric : $93 \%$ vs.

Table 1. Genes closely correlated with ependymoma

\begin{tabular}{|c|c|c|c|c|c|c|}
\hline Locus & Gene & Author & Spinal & Intracranial & $p$ & Comments \\
\hline \multirow[t]{4}{*}{$22 \mathrm{q} 12$} & NF2 mutation & Ebert et al. $^{7)}$ & $6 / 17(35 \%)$ & $0 / 39(0 \%)$ & 0.0063 & E II, 6/8 (75\%) \\
\hline & & Bettegowda et al." & $9 / 19(47 \%)$ & $0 / 40(0 \%)$ & 0.0002 & \\
\hline & & Lamszus et al. $^{21)}$ & $5 / 31(16 \%)$ & $0 / 14(0 \%)$ & $0.30^{*}$ & E II, 3/23(13\%); E III, 2/4 (50\%) \\
\hline & & Singh et al. ${ }^{38)}$ & $5 / 14(36 \%)$ & $1 / 11(9 \%)$ & 0.180 & E II, 4/10 (40\%); MPE, 1/4 (25\%) \\
\hline $17 \mathrm{p} 13$ & HIC-1 methylation & Waha et al. ${ }^{44)}$ & $13 / 20(65 \%)$ & $30 / 32(94 \%)$ & 0.019 & \\
\hline $18 \mathrm{p} 11$ & $4.1 B$ deletion & Rajaram et al. $^{30)}$ & $8 / 32(25 \%)$ & $24 / 49(49 \%)$ & 0.038 & \\
\hline $8 \mathrm{p} 21$ & NEFL overexpression & Barton et al. ${ }^{4)}$ & $10 / 21(48 \%)$ & $1 / 12(8 \%)$ & $0.03^{*}$ & MPE 8/13 (62\%) \\
\hline $9 q 33$ & TNC overexpression & Gupta et al. ${ }^{12)}$ & $3 / 19(16 \%)$ & $13 / 31(42 \%)$ & 0.05 & ST, 5/15 (33\%); PF, 8/16 (50\%) \\
\hline $11 q 13$ & MEN1 mutation & Lamszus et al. $^{21)}$ & $0 / 27(0 \%)$ & $1 / 12(8 \%)$ & $0.31^{\star}$ & \\
\hline $17 \mathrm{q} 21$ & HOXB13 overexpression & Barton et al. ${ }^{4)}$ & $10 / 21(48 \%)$ & $2 / 9(22 \%)$ & $0.25^{\star}$ & MPE 9/13 (69\%) \\
\hline $8 q 11-12$ & $c$-mos expression & Athanasiou et al. & $1 / 5(20 \%)$ & $15 / 29(52 \%)$ & $0.34^{*}$ & \\
\hline $18 \mathrm{p} 11$ & $D A L-1$ deletion & Singh et al. ${ }^{38)}$ & $2 / 14(14 \%)$ & $4 / 11(36 \%)$ & 0.35 & \\
\hline $9 q 34$ & NOTCH1 expression & Gupta et al. ${ }^{12)}$ & $5 / 19(26 \%)$ & $13 / 31(42 \%)$ & $0.37^{\star}$ & ST, 11/15 (73\%); PF 3/16 (19\%) \\
\hline $9 q 22$ & SHC3/S1PR3 (EDG3) expression & Magrassi et al. ${ }^{23)}$ & $10 / 19(53 \%)$ & $11 / 16(69 \%)$ & $0.49^{*}$ & \\
\hline $9 \mathrm{p} 21$ & $C D K N 2 A\left(P 16^{I N K 4 A}\right)$ deletion & Rajaram et al. $^{31)}$ & $12 / 47(26 \%)$ & $15 / 45(33 \%)$ & $0.49^{*}$ & \\
\hline $3 \mathrm{p} 21$ & RASSF1 (RASSF1A) methylation & Hamilton et al. ${ }^{14)}$ & $18 / 20(90 \%)$ & $12 / 15(80 \%)$ & $0.63^{*}$ & \\
\hline $13 q 14$ & $R B$ deletion & Rajaram et al. $^{31)}$ & $12 / 47(26 \%)$ & $10 / 45(22 \%)$ & $0.81^{\star}$ & \\
\hline $4 q 12$ & PDGFRA overexpression & Barton et al. ${ }^{4)}$ & $16 / 19(84 \%)$ & $11 / 13(85 \%)$ & $1.00^{*}$ & MPE, 11/13 (85\%) \\
\hline $17 \mathrm{q} 12$ & $E R B B 2$ expression & Gilberston et al. $^{10)}$ & $1 / 1(100 \%)$ & $64 / 78(82 \%)$ & $1.00^{*}$ & Pediatric patients \\
\hline \multirow[t]{2}{*}{$10 q 23$} & PTEN mutation & Bettegowda et al." & $0 / 8(0 \%)$ & $1 / 8(13 \%)$ & $1.00^{*}$ & \\
\hline & & Ebert et al. & $0 / 23(0 \%)$ & $0 / 39(0 \%)$ & $1.00^{*}$ & \\
\hline
\end{tabular}

${ }^{\star} p$-value calculated by $2 \times 2$ table. E II : ependymoma (WHO Grade II), E III : anaplastic ependymoma (WHO grade III), MPE : myxopapillary ependymoma, ST : supratentorial ependymoma, PF : posterior fossa ependymoma

Table 2. Proteins closely correlated with ependymoma

\begin{tabular}{|c|c|c|c|c|c|}
\hline Protein & Gene & Author & Spinal & Intracranial & $p$ \\
\hline \multirow[t]{2}{*}{ Merlin loss } & NF2 & Singh et al. ${ }^{38)}$ & $5 / 15(33 \%)$ & $0 / 12(0 \%)$ & 0.047 \\
\hline & & Rajaram et al. $^{30)}$ & $2 / 5(40 \%)$ & $0 / 4(0 \%)$ & $0.44^{*}$ \\
\hline 4.1R loss & $E P B 41(4.1 R)$ & Rajaram et al. $^{30)}$ & $47 \%$ & $88 \%$ & 0.003 \\
\hline DAL-1 loss & EPB41L3 & Singh et al. ${ }^{38)}$ & $2 / 15(13 \%)$ & $5 / 12(42 \%)$ & 0.185 \\
\hline 4.1B loss & $E P B 41 L 3$ & Rajaram et al. $^{30)}$ & $1 / 5(20 \%)$ & $3 / 4(75 \%)$ & $0.21^{*}$ \\
\hline HES1 overexpression & HES1 & Gupta et al. ${ }^{12)}$ & $10 / 19(53 \%)$ & $10 / 31(32 \%)$ & $0.23^{*}$ \\
\hline MYC overexpression & $M Y C$ & Gupta et al. ${ }^{12)}$ & $12 / 19(63 \%)$ & $14 / 31(45 \%)$ & $0.25^{\star}$ \\
\hline HEY2 overexpression & $H E Y 2$ & Gupta et al. $^{12)}$ & $11 / 19(58 \%)$ & $20 / 31(65 \%)$ & $0.77^{\star}$ \\
\hline GFAP expression $^{\dagger}$ & GFAP & Hagel et al. ${ }^{13)}$ & $4 / 4(100 \%)$ & $15 / 21(71 \%)$ & $0.54^{*}$ \\
\hline MDM2 overexpression & MDM2 & Suzuki and Iwaki ${ }^{39)}$ & $4 / 5(80 \%)$ & $17 / 21(81 \%)$ & $1.00^{*}$ \\
\hline NeuN expression ${ }^{\dagger}$ & RBFOX2 & Hagel et al. ${ }^{13)}$ & $1 / 4(25 \%)$ & $5 / 21(24 \%)$ & $1.00^{*}$ \\
\hline p75 expression ${ }^{\dagger}$ & NGFR & Hagel et al. ${ }^{13)}$ & $0 / 4(0 \%)$ & $3 / 21(14 \%)$ & $1.00^{*}$ \\
\hline
\end{tabular}

${ }^{*} p$-value calculated by $2 \times 2$ table, ${ }^{\dagger}$ Protein expression of immunohistochemistry was defined as moderate or strong staining 
adult : $48 \% ; p<0.001$ ), although presence of $4.1 R$ deletion did not differ substantially between subsets according to tumor location and age ${ }^{30}$.

\section{NEFL, HOXB13, and PDGFRA}

MPE is regarded to be distinct molecularly from intracranial ependymoma as well as other spinal ependymomas. MPE is characterized by high expression levels of some genes, including $N E F L$, HOXB13, and PDGFRA $A^{4}$. A previous study reported that NEFL immunoreactivity in the spinal ependymoma was substantially high compared to that in intracranial ependymoma in Table 1 (spinal : $48 \%$ vs. intracranial : $8 \% ; p=0.03)^{4)}$. NEFL immunoreactivity was positive in 8 of $13(62 \%)$ MPE cases, which is very high compared with subependymoma and ependymomas in both spinal and intracranial region. Another study reported that high expression of NEFL could predict a longer progression-free survival in supratentorial ependymomas ${ }^{2}$.

Both HOXB13 and PDGFRA genes were investigated in one paper and there was not a significant difference in immunoreactivity by tumor location ${ }^{4}$. This study also found that PDGFRA demonstrated high sensitivity but poor specificity for ependymoma, since most intracranial ependymoma cases were positive as well. The upregulation of PDGFRA suggests that the therapeutic targeting of this receptor tyrosine kinase may be an appropriate topic for future clinical trials. Several PDGFRA inhibitors have been FDA approved, including imatinib mesylate, sorafenib, and sunitinib ${ }^{4)}$.

\section{TNC and NOTCH1}

Tenascin C (TNC) and NOTCH1 genes are located on chromosomes $9 \mathrm{q} 33$ and $9 \mathrm{q} 34$, respectively, and are involved in central nervous system embryogenesis. Previous studies have reported the gain of 9q in ependymoma, which is where TNC and NOTCH1 genes are located ${ }^{12,16,23,36)}$. One study analyzed the correlation between $T N C$ and ependymoma and reported that the immunoexpression of TNC was higher in intracranial ependymoma than in its spinal counterpart $(p=0.05)^{12}$. In this study, the immunoexpression of $T N C$ was positive in $50 \%$ of posterior fossa cases compared with $19 \%$ of spinal ependymoma cases and $31 \%$ of supratentorial ependymoma cases. Immunotherapy using radiolabeled anti-TNC antibodies has shown promising results for hematological malignancies and brain tumors ${ }^{32}$. Immunotherapy using anti-TNC antibodies may be a useful in the future.

One study showed no significant difference in NOTCH1 expression between intracranial and spinal ependymomas in Table 1 (intracranial : $42 \%$ vs. spinal : $26 \%$; $p=0.37$ ). However, NOTCH1 showed significantly higher immunoexpression in supratentorial tumors $(73 \%)$ in comparison to infratentorial $(19 \% ; p=0.001)$ and spinal $(26 \% ; p=0.01)$ tumors ${ }^{12)}$. Notch pathway activation leads to the overexpression of the target genes HES1, HEY2, and MYC. The expression levels of the proteins (HES1, HEY2, and MYC) of these genes were not substantially differ- ent according to tumor location in Table $2^{12}$. A Notch pathway enzyme, $\gamma$-secretase inhibitors may represent a promising therapeutic option for supratentorial ependymomas in future ${ }^{12,29)}$.

\section{SHC3 and S1PR3}

SHC3 and S1PR3 genes are located on chromosome 9q22.12. Dysregulation of $S H C 3$ expression is involved in the survival of anaplastic astrocytomas and glioblastomas ${ }^{22}$. The S1PR3 gene is also known as $E D G 3$ and likely contributes to the regulation of angiogenesis and vascular endothelial cell function. The coimmunoprecipitation of Shc3 and EDG3 proteins was reported in ependymomas with amplification of $S H C 3$ and EDG3 genes, which suggests that the 2 proteins co-operate and are important for ependymomas ${ }^{23}$. However, the differences in gene mutations and protein overexpression were not substantial between spinal and intracranial ependymomas.

\section{MEN1}

The MEN1 gene is located on chromosome 11q13, a region that is involved in allelic losses and rearrangements in ependymomas. Ependymomas have been described in patients with MEN1 syndrome, which is characterized by the development of multiple endocrine tumors ${ }^{6}$. However, mutations in the MEN1 gene have been described in only a small fraction of recurrent ependymomas ${ }^{6}$. In one study, only 1 intracranial ependymoma patient had an MEN1 mutation among the 12 intracranial and 27 spinal ependymoma patients ${ }^{21}$. The patient with the MEN1 mutation exhibited lesion recurrence twice and metastasis.

\section{$R B$ and $C D K N 2 A\left(P 16^{I N K A A}\right)$}

Retinoblastoma susceptibility $(R B)$ gene on chromosome 13q14 and cyclin-dependent kinase inhibitor 2A (CDKN2A) gene, also known as $P 16^{I N K 4 A}$, on chromosome 9p21 are key tumor suppressor genes in a cell cycle regulatory pathway that is commonly inactivated in a wide range of cancers. The disruption of either $R B$ or $C D K N 2 A$ gene leads to deregulated cell proliferation and supports tumor progression ${ }^{37)}$. Several studies reported that there were no significant genetic associations of $9 p$ and $13 q$ with ependymoma grade, recurrence, or death, suggesting that $9 \mathrm{p}$ and 13q deletions do not have obvious associations with tumor grade, age, location, or overall prognosis in Table $1^{11,31)}$. Therefore, they might not play a prominent role in the malignant progression of ependymomas ${ }^{31)}$.

\section{c-mos}

c-mos, the proto-oncogene located on chromosome 8q11-12 in humans, encodes mos, a $39-\mathrm{kD}$ protein that is a component of the mitogen-activated protein kinase transduction pathway ${ }^{3}$. In one study, almost half of the ependymal tumors were immunopositive for mos, and overexpression of mos identified a biologically aggressive subgroup of ependymal tumors ${ }^{3}$. However, only 5 spinal ependymoma cases were enrolled among the 34 tumor cases, and the expression incidence of $c$-mos gene did not 
differ significantly by location in Table 1 (intracranial : $52 \%$ vs. spinal : $20 \%$; $p=0.34$ ).

\section{RASSF1 (RASSF1A)}

Ras association domain family protein 1 , isoform A (RASSF1) gene is located on chromosome $3 \mathrm{p} 21.3$ and has been shown to be involved in a variety of malignancies, including brain tumors such as gliomas and medulloblastomas ${ }^{14)}$. Recent evidence has also suggested that the extensive hypermethylation of tumor suppressor genes, including CDKN2A, CDKN2B, HIC1, RASS$F 1 A, C A S P 8, M G M T$, and TP73, is an important mechanism in the pathogenesis of ependymoma ${ }^{33)}$. Rajaram et al. ${ }^{31)}$ reported that extensive hypermethylation across the RASSF1 CpG island was detected frequently in 18 of 20 (90\%) spinal ependymomas and 12 of 15 (80\%) intracranial ependymomas. The incidence of RASSF1 hypermethylation was not different between spinal and intracranial ependymomas. Other researchers reported that both supratentorial and spinal ependymomas frequently displayed RASSF1 gene hypermethylation, whereas posterior fossa tumors did not ${ }^{33)}$. Thus, the absence of RASSF1A hypermethylation may be a diagnostic indicator of posterior fossa ependymoma.

\section{ERBB2}

$E R B B 2$ gene is a member of the RTK I family and is located on chromosome 17q12. This gene encodes a member of the epidermal growth factor receptor (EGFR) family of receptor tyrosine kinases. The ErbB2 receptor was reported to be frequently overexpressed in childhood intracranial ependymoma ${ }^{10)}$, with the expression of ErbB2 identified in $82 \%$ of tumors. However, only one spinal ependymoma case was enrolled among the 121 tumor cases, and the expression difference by tumor location was not significant.

Another study demonstrated that Merlin negatively regulated spinal neural progenitor cell survival and glial differentiation in an ErbB2-dependent manner and that NF2-associated spinal ependymomas exhibited increased ErbB2 activation, indicating that ErbB2 may be a potential therapeutic target for NF2-associated spinal ependymoma ${ }^{9)}$. The importance of ERBB2 in NF2associated tumors is also highlighted by recent research showing that lapatinib inhibits vestibular schwannoma growth ${ }^{1)}$.

\section{MDM2}

Oncogene $M D M 2$, localized on chromosome 12q14-15, encodes a nuclear-localized E3 ubiquitin ligase. The encoded protein, MDM2, can promote tumor formation by targeting tumor suppressor proteins, such as p53, for proteasomal degradation. Thus, the protein is believed to act as a cellular regulator of the p53 $\operatorname{protein}^{39)}$. One previous study showed that MDM2 was overexpressed at similar levels in intracranial and spinal ependymomas in Table 2 (intracranial : $81 \%$ vs. spinal : $80 \% ; p=1.00)^{39}$.

\section{TP53}

The TP53 tumor suppressor gene on chromosome $17 \mathrm{p} 13.1$ is frequently mutated in human cancers, and it is important in the pathogenesis of other central nervous system tumors ${ }^{8)}$. One study found that TP53 was mutated in only 1 of 31 ependymomas patients ${ }^{8)}$, and another study reported that TP53 was mutated in only 1 of 16 patients ${ }^{5)}$. Therefore, TP53 does not seem to be important in the pathogenesis of ependymomas, unlike other brain tumor types in which p53 mutations play a role in the progression of tumors ${ }^{8)}$.

\section{PTEN}

PTEN gene, located on chromosome 10q23, has been proposed to be a candidate tumor suppressor gene that is inactivated in multiple cancers, including glial tumors. Three studies investigate the relation between PTEN and ependymoma, and all studies found that PTEN mutations are rarely present in ependymo$\mathrm{ma}^{5,7,52)}$. Only one patient with a PTEN mutation had an intracranial tumor, but this patient also had a TP53 mutation ${ }^{5)}$.

\section{GFAP, NeuN, and p75}

Prior study suggested that immunohistochemical (IHC) expression of p75, NeuN and GFAP differed in ependymomas depending on tumor topography supporting the view of divergent cells of origin ${ }^{13)}$. They showed that glial markers such as NeuN and GFAP were preferentially expressed in infratentorial lesions, whereas neuronal markers such as p75 were found in supratentorial tumors, which reached statistically significant difference between supratentorial and infratentorial ependymoma for p75, GFAP, and $\mathrm{NeuN}^{13)}$. However, the difference between spinal and intracranial tumors did not show a statistical significance for $\mathrm{p} 75$, GFAP, and NeuN.

\section{CYTOGENETIC ABERRATIONS}

\section{Chromosome 9q gain and loss of heterozygosity (LOH) 9}

Gene amplification is an important mechanism to enhance gene expression in many tumors. Large gains and losses of the long arm of chromosome 9 have been repeatedly described in studies using cytogenetic and molecular analyses of ependymomas, and 9q gain was mapped to 9q12-32 and 9q22-31 intervals $^{12,23,51)}$. A study that included 50 patients reported that chromosome 9q33-34 gain was more frequently observed in spinal ependymoma than in intracranial counterpart in Table 3 (intracranial : $29 \%$ vs. spinal : $79 \%$; $p=0.001$ ), which showed a statistically significant difference ${ }^{12)}$. Another study involving 35 patients reported that chromosome 9q22-22.2 gain was commonly detected in both spinal and intracranial ependymomas in Table 3 (intracranial : $69 \%$ vs. spinal : $53 \% ; p=0.49)^{23}$ ).

Two studies investigated $9 q$ deletion in ependymoma ${ }^{16,36)}$, and neither found a substantial difference between spinal and intracranial ependymomas. In a study that included 48 patients with ependymoma, 9q deletions, particularly of DCR1, were found significantly more often in supratentorial tumors than in tumors with an infratentorial location in pediatric patients $(p=0.007)^{36)}$. 
Table 3. Chromosomal aberrations closely correlated with ependymoma

\begin{tabular}{|c|c|c|c|c|}
\hline Chromosome & Author & Spinal & Intracranial & $p$ \\
\hline \multirow[t]{2}{*}{ 9q gain } & Gupta et al. ${ }^{12)}$ & $15 / 19(79 \%)$ & 9/31 (29\%) & $0.01^{\star}$ \\
\hline & Magrassi et al. ${ }^{23)}$ & $10 / 19(53 \%)$ & $11 / 16(69 \%)$ & $0.49^{*}$ \\
\hline \multirow[t]{5}{*}{ LOH 22} & Ebert et al..$^{7)}$ & $7 / 19(37 \%)$ & $6 / 39(15 \%)$ & 0.2 \\
\hline & Huang et al. ${ }^{15)}$ & $6 / 14(43 \%)$ & $6 / 19(32 \%)$ & $0.72^{*}$ \\
\hline & Bettegowda et al. ${ }^{5)}$ & $7 / 8(88 \%)$ & $5 / 8(63 \%)$ & $0.57^{\star}$ \\
\hline & Lamszus et al. ${ }^{21)}$ & $16 / 31(52 \%)$ & $4 / 14(29 \%)$ & $0.20^{*}$ \\
\hline & Kraus et al. ${ }^{20)}$ & $7 / 15(47 \%)$ & $4 / 20(20 \%)$ & $0.29^{*}$ \\
\hline \multirow[t]{2}{*}{$\mathrm{LOH} 9$} & Schneider et al. ${ }^{36)}$ & $10 / 18(56 \%)$ & $20 / 30(67 \%)$ & $0.54^{*}$ \\
\hline & Huang et al. ${ }^{16)}$ & $3 / 13(23 \%)$ & $6 / 20(30 \%)$ & $1.00^{*}$ \\
\hline \multirow[t]{3}{*}{ 6q deletion } & Monoranu et al. ${ }^{25)}$ & $14 / 18(78 \%)$ & $20 / 31(65 \%)$ & $0.52^{*}$ \\
\hline & Huang et al. ${ }^{16)}$ & $5 / 13(38 \%)$ & $6 / 20(20 \%)$ & $0.71^{\star}$ \\
\hline & Olsen et al. ${ }^{26)}$ & $1 / 3(33 \%)$ & $6 / 14(43 \%)$ & $1.00^{*}$ \\
\hline LOH 11q & Lamszus et al. $^{21)}$ & $3 / 31(10 \%)$ & 4/14 (29\%) & $0.18^{\star}$ \\
\hline $\mathrm{LOH} 10 \mathrm{q}$ & Ebert et al. $^{7)}$ & $2 / 22(9 \%)$ & $3 / 34(9 \%)$ & $1.00^{*}$ \\
\hline
\end{tabular}

${ }^{*} p$-value calculated by $2 \times 2$ table. $\mathrm{LOH}$ : loss of heterozygosity

\section{LOH 22q}

The most frequent genetic change in sporadic ependymomas is monosomy 22, suggesting the presence of an ependymoma tumor suppressor gene on chromosome $22^{15)}$. The majority of relevant studies reported that $\mathrm{LOH}$ of $22 \mathrm{q}$ was more frequent in spinal ependymoma than in intracranial ependymoma, although this difference did not reach statistical significance ${ }^{5,7,15,20,21)}$. Although NF2 gene mutations are observed distinctively in spinal ependymoma, no clear association between LOH 22 and NF2 mutations has been found. Hence, these data may either suggest the presence of another tumor suppressor gene on chromosome 22 or result from a chromosomal instability causing the random deletion of genomic material ${ }^{5,7)}$.

\section{Chromosome $6 q$ deletion}

Losses and rearrangements of genetic material on chromosome $6 \mathrm{q}$ are frequently detected in human malignancies, including central nervous system tumors such as gliomas ${ }^{25)}$. Three studies reported a correlation between chromosome $6 \mathrm{q}$ deletion and ependymoma ${ }^{16,25,26)}$, and the incidences of $6 q$ deletion between spinal and intracranial ependymomas were similar.

\section{LOH of $10 q$ and $11 q$}

In studies of $\mathrm{LOH}$ of chromosomes 10 and 11, no correlation between the tumor location and the $\mathrm{LOH}$ was observed ${ }^{7,21)}$. One study found that $\mathrm{LOH}$ of $10 \mathrm{q}$ was observed regardless of tumor location, showing a trend related to tumor grade (WHO grade III : $24 \%$; WHO grade II : $4 \%$; WHO grade I : $0 \%)^{7}$. Another study reported that $\mathrm{LOH}$ of $11 \mathrm{q}$ was associated with neither tumor location nor tumor grade ${ }^{21)}$ and that there was a highly significant inverse association between LOH 11q and LOH 22q, which suggests that loss of genetic information on either $11 \mathrm{q}$ or $22 \mathrm{q}$ could represent independent and alternative mechanisms involved in ependymoma pathogenesis.

\section{CONCLUSION}

Spinal ependymoma has been found to be quite different from intracranial ependymoma in genetic studies, and the favorable prognosis in spinal ependymoma may be due to these genetic differences. Ependymoma in the spinal cord may be related with NF2 mutations, NEFL overexpression, and 9q gain. Its intracranial counterpart may be related with $H I C-1$ methylation, $4.1 \mathrm{~B}$ deletion, and 4.1R loss. A more detailed understanding of these various genetic aberrations may enable the identification of more specific prognostic markers as well as the development of customized targeted therapies.

\section{- Acknowledgements}

This research was supported by Basic Science Research Program through the National Research Foundation of Korea (NRF) funded by the Ministry of Science, ICT and future Planning (2014R1A2A1A11049662).

\section{References}

1. Ahmad ZK, Brown CM, Cueva RA, Ryan AF, Doherty JK : ErbB expression, activation, and inhibition with lapatinib and tyrphostin (AG825) in human vestibular schwannomas. Otol Neurotol 32 : 841-847, 2011

2. Andreiuolo F, Puget S, Peyre M, Dantas-Barbosa C, Boddaert N, Philippe $\mathrm{C}$, et al. : Neuronal differentiation distinguishes supratentorial and infratentorial childhood ependymomas. Neuro Oncol 12 : 1126-1134, 2010

3. Athanasiou A, Perunovic B, Quilty RD, Gorgoulis VG, Kittas C, Love S : Expression of mos in ependymal gliomas. Am J Clin Pathol 120 : 699705,2003

4. Barton VN, Donson AM, Kleinschmidt-DeMasters BK, Birks DK, Handler MH, Foreman NK : Unique molecular characteristics of pediatric myxopapillary ependymoma. Brain Pathol 20 : 560-570, 2010

5. Bettegowda C, Agrawal N, Jiao Y, Wang Y, Wood LD, Rodriguez FJ, et al. : Exomic sequencing of four rare central nervous system tumor types. Oncotarget $4: 572-583,2013$

6. de Bont JM, Packer RJ, Michiels EM, den Boer ML, Pieters R : Biological background of pediatric medulloblastoma and ependymoma : a review from a translational research perspective. Neuro Oncol 10 : 10401060, 2008

7. Ebert C, von Haken M, Meyer-Puttlitz B, Wiestler OD, Reifenberger G, Pietsch T, et al. : Molecular genetic analysis of ependymal tumors. NF2 mutations and chromosome 22q loss occur preferentially in intramedullary spinal ependymomas. Am J Pathol 155 : 627-632, 1999

8. Fink KL, Rushing EJ, Schold SC Jr, Nisen PD : Infrequency of p53 gene mutations in ependymomas. J Neurooncol 27 : 111-115, 1996

9. Garcia C, Gutmann DH : Nf2/Merlin controls spinal cord neural progenitor function in a Rac1/ErbB2-dependent manner. PLoS One 9 : e97320, 2014

10. Gilbertson RJ, Bentley L, Hernan R, Junttila TT, Frank AJ, Haapasalo H, et al. : ERBB receptor signaling promotes ependymoma cell proliferation and represents a potential novel therapeutic target for this disease. Clin Cancer Res 8 : 3054-3064, 2002

11. Gonzalez-Gomez P, Bello MJ, Alonso ME, Arjona D, Lomas J, de Campos JM, et al. : CpG island methylation status and mutation analysis of the RB1 gene essential promoter region and protein-binding pocket domain in nervous system tumours. Br J Cancer 88 : 109-114, 2003

12. Gupta RK, Sharma MC, Suri V, Kakkar A, Singh M, Sarkar C : Study of chromosome 9q gain, Notch pathway regulators and Tenascin-C in ependymomas. J Neurooncol $116: 267-274,2014$ 
13. Hagel C, Treszl A, Fehlert J, Harder J, von Haxthausen F, Kern M, et al. : Supra- and infratentorial pediatric ependymomas differ significantly in NeuN, p75 and GFAP expression. J Neurooncol 112 : 191-197, 2013

14. Hamilton DW, Lusher ME, Lindsey JC, Ellison DW, Clifford SC : Epigenetic inactivation of the RASSF1A tumour suppressor gene in ependymoma. Cancer Lett $227:$ 75-81, 2005

15. Huang B, Starostik P, Kühl J, Tonn JC, Roggendorf W : Loss of heterozygosity on chromosome 22 in human ependymomas. Acta Neuropathol $103: 415-420,2002$

16. Huang B, Starostik P, Schraut H, Krauss J, Sörensen N, Roggendorf W : Human ependymomas reveal frequent deletions on chromosomes 6 and 9. Acta Neuropathol $106: 357-362,2003$

17. Johnson RA, Wright KD, Poppleton H, Mohankumar KM, Finkelstein D, Pounds SB, et al. : Cross-species genomics matches driver mutations and cell compartments to model ependymoma. Nature 466 : 632-636, 2010

18. Kilday JP, Rahman R, Dyer S, Ridley L, Lowe J, Coyle B, et al. : Pediatric ependymoma : biological perspectives. Mol Cancer Res 7 : 765-786, 2009

19. Korshunov A, Witt H, Hielscher T, Benner A, Remke M, Ryzhova M, et al. : Molecular staging of intracranial ependymoma in children and adults. J Clin Oncol 28 : 3182-3190, 2010

20. Kraus JA, de Millas W, Sörensen N, Herbold C, Schichor C, Tonn JC, et al. : Indications for a tumor suppressor gene at 22q11 involved in the pathogenesis of ependymal tumors and distinct from hSNF5/INI1. Acta Neuropathol $102: 69-74,2001$

21. Lamszus K, Lachenmayer L, Heinemann U, Kluwe L, Finckh U, Höppner W, et al. : Molecular genetic alterations on chromosomes 11 and 22 in ependymomas. Int J Cancer 91 : 803-808, 2001

22. Magrassi L, Conti L, Lanterna A, Zuccato C, Marchionni M, Cassini P, et al. : Shc3 affects human high-grade astrocytomas survival. Oncogene 24:5198-5206, 2005

23. Magrassi L, Marziliano N, Inzani F, Cassini P, Chiaranda I, Skrap M, et al. : EDG3 and SHC3 on chromosome 9q22 are co-amplified in human ependymomas. Cancer Lett $290: 36-42,2010$

24. Modena P, Lualdi E, Facchinetti F, Veltman J, Reid JF, Minardi S, et al. : Identification of tumor-specific molecular signatures in intracranial ependymoma and association with clinical characteristics. J Clin Oncol 24: 5223-5233, 2006

25. Monoranu CM, Huang B, Zangen IL, Rutkowski S, Vince GH, Gerber NU, et al. : Correlation between 6q25.3 deletion status and survival in pediatric intracranial ependymomas. Cancer Genet Cytogenet 182 : $18-26,2008$

26. Olsen TK, Gorunova L, Meling TR, Micci F, Scheie D, Due-Tønnessen B, et al. : Genomic characterization of ependymomas reveals $6 \mathrm{q}$ loss as the most common aberration. Oncol Rep 32 : 483-490, 2014

27. Pajtler KW, Witt H, Sill M, Jones DT, Hovestadt V, Kratochwil F, et al. : Molecular classification of ependymal tumors across all CNS compartments, histopathological grades, and age groups. Cancer Cell 27 : 728 743, 2015

28. Parker M, Mohankumar KM, Punchihewa C, Weinlich R, Dalton JD, Li $\mathrm{Y}$, et al. : C11orf95-RELA fusions drive oncogenic NF- $\mathrm{KB}$ signalling in ependymoma. Nature 506 : 451-455, 2014

29. Puget S, Grill J, Valent A, Bieche I, Dantas-Barbosa C, Kauffmann A, et al. : Candidate genes on chromosome 9q33-34 involved in the progression of childhood ependymomas. J Clin Oncol 27 : 1884-1892, 2009

30. Rajaram V, Gutmann DH, Prasad SK, Mansur DB, Perry A : Alterations of protein 4.1 family members in ependymomas : a study of 84 cases. Mod Pathol 18 : 991-997, 2005

31. Rajaram V, Leuthardt EC, Singh PK, Ojemann JG, Brat DJ, Prayson RA, et al. : 9p21 and 13q14 dosages in ependymomas. A clinicopathologic study of 101 cases. Mod Pathol $17:$ 9-14, 2004

32. Reardon DA, Akabani G, Coleman RE, Friedman AH, Friedman HS, Herndon JE 2nd, et al. : Salvage radioimmunotherapy with murine iodine-131-labeled antitenascin monoclonal antibody 81C6 for patients with recurrent primary and metastatic malignant brain tumors : phase II study results. J Clin Oncol 24 : 115-122, 2006

33. Rogers HA, Kilday JP, Mayne C, Ward J, Adamowicz-Brice M, Schwalbe EC, et al. : Supratentorial and spinal pediatric ependymomas display a hypermethylated phenotype which includes the loss of tumor suppressor genes involved in the control of cell growth and death. Acta Neuropathol $123: 711-725,2012$

34. Rubio MP, Correa KM, Ramesh V, MacCollin MM, Jacoby LB, von Deimling A, et al. : Analysis of the neurofibromatosis 2 gene in human ependymomas and astrocytomas. Cancer Res 54 : 45-47, 1994

35. Scheil S, Brüderlein S, Eicker M, Herms J, Herold-Mende C, Steiner HH, et al. : Low frequency of chromosomal imbalances in anaplastic ependymomas as detected by comparative genomic hybridization. Brain Pathol $11: 133-143,2001$

36. Schneider D, Monoranu CM, Huang B, Rutkowski S, Gerber NU, Krauss J, et al. : Pediatric supratentorial ependymomas show more frequent deletions on chromosome 9 than infratentorial ependymomas : a microsatellite analysis. Cancer Genet Cytogenet 191 : 90-96, 2009

37. Sherr CJ : The INK4a/ARF network in tumour suppression. Rev Mol Cell Biol 2 : 731-737, 2001

38. Singh PK, Gutmann DH, Fuller CE, Newsham IF, Perry A : Differential involvement of protein 4.1 family members DAL-1 and NF2 in intracranial and intraspinal ependymomas. Mod Pathol 15 : 526-531, 2002

39. Suzuki SO, Iwaki $\mathrm{T}$ : Amplification and overexpression of $\mathrm{mdm} 2$ gene in ependymomas. Mod Pathol 13 : 548-553, 2000

40. Taylor MD, Poppleton H, Fuller C, Su X, Liu Y, Jensen P, et al. : Radial glia cells are candidate stem cells of ependymoma. Cancer Cell $8: 323-$ 335,2005

41. Teo C, Nakaji P, Symons P, Tobias V, Cohn R, Smee R : Ependymoma. Childs Nerv Syst 19:270-285, 2003

42. Vera-Bolanos E, Aldape K, Yuan Y, Wu J, Wani K, Necesito-Reyes MJ, et al. : Clinical course and progression-free survival of adult intracranial and spinal ependymoma patients. Neuro Oncol $17: 440-447,2015$

43. von Haken MS, White EC, Daneshvar-Shyesther L, Sih S, Choi E, Kalra $\mathrm{R}$, et al. : Molecular genetic analysis of chromosome arm 17p and chromosome arm 22q DNA sequences in sporadic pediatric ependymomas. Genes Chromosomes Cancer 17 : 37-44, 1996

44. Waha A, Koch A, Hartmann W, Mack H, Schramm J, Sörensen N, et al. : Analysis of HIC-1 methylation and transcription in human ependymomas. Int J Cancer 110 : 542-549, 2004

45. Wang Z, Zhang J, Ye M, Zhu M, Zhang B, Roy M, et al. : Tumor suppressor role of protein 4.1B/DAL-1. Cell Mol Life Sci 71 : 4815-4830, 2014

46. Wani K, Armstrong TS, Vera-Bolanos E, Raghunathan A, Ellison D, Gilbertson R, et al. : A prognostic gene expression signature in infratentorial ependymoma. Acta Neuropathol 123 : 727-738, 2012

47. Ward S, Harding B, Wilkins P, Harkness W, Hayward R, Darling JL, et al. : Gain of $1 \mathrm{q}$ and loss of 22 are the most common changes detected by comparative genomic hybridisation in paediatric ependymoma. Genes Chromosomes Cancer 32 : 59-66, 2001

48. Witt H, Mack SC, Ryzhova M, Bender S, Sill M, Isserlin R, et al. : Delineation of two clinically and molecularly distinct subgroups of posterior fossa ependymoma. Cancer Cell 20 : 143-157, 2011

49. Yang I, Nagasawa DT, Kim W, Spasic M, Trang A, Lu DC, et al. : Chromosomal anomalies and prognostic markers for intracranial and spinal ependymomas. J Clin Neurosci 19: 779-785, 2012

50. Zadnik PL, Gokaslan ZL, Burger PC, Bettegowda C: Spinal cord tumours : advances in genetics and their implications for treatment. Nat Rev Neu- 
rol 9: 257-266, 2013

51. Zheng PP, Pang JC, Hui AB, Ng HK : Comparative genomic hybridization detects losses of chromosomes 22 and 16 as the most common recurrent genetic alterations in primary ependymomas. Cancer Genet $\mathrm{Cy}$ - togenet 122: 18-25, 2000

52. Zhou XP, Li YJ, Hoang-Xuan K, Laurent-Puig P, Mokhtari K, Longy M, et al. : Mutational analysis of the PTEN gene in gliomas : molecular and pathological correlations. Int J Cancer 84 : 150-154, 1999 